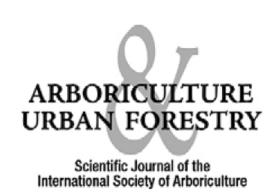

\title{
Tree Health in Phoenix, Arizona, U.S.
}

\author{
Chris A. Martin and Jean C. Stutz
}

\begin{abstract}
Two studies of tree diversity, visual health, and mortality in the Phoenix, Arizona, U.S. metropolitan basin were conducted as part of the Central Arizona Long-Term Ecological Research project. For one study, tree diversity, mortality, and visual health were determined in 2010 at 204 sites, encompassing both the Phoenix metropolitan basin and in the surrounding Sonoran Desert. In another study, records of tree visual health and mortality were taken during the winter months (2003-2007) at 65 non-residential sites across an urban to rural gradient. Average tree mortality rates were $4.2 \%$ per annum. Crown condition was rated as very good or good for the majority of trees. Poor pruning practices and abiotic injuries, such as trunk sunscald, were observed on $70 \%$ and $23 \%$, respectively, of trees in non-residential areas. Disease and pest problems were detected in $41 \%$ of urban trees, including wood decay, Verticillium wilt, sooty canker, and ash decline. Based on these data, researchers suggest that urban forest health in Phoenix is being negatively impacted by extensive wounding of trees, particularly in non-residential settings, possibly caused by excessive crown manipulation through pruning. Key Words. Arizona; Phoenix; Tree Diversity; Tree Mortality; Urban Forest; Urban Heating.
\end{abstract}

Cities first appeared as complex social structures nearly 10,000 years ago. Many of the earliest cities developed in arid climates near reliable fresh river water resources (Redman 1999). "Oasis" is a term that is often used to describe desert cities with abundant perennial fresh water resources because of their many concentrated garden landscapes and increased tree cover. The Phoenix metropolitan area in Maricopa County, Arizona, U.S. is an archetypical modern day oasis urban center, and is situated at the northeast fringe of the lower Sonoran Desert in the broad Salt River basin. During the 20th century, construction of local water storage reservoirs along the regional Aqua Fria, Gila, Salt, and Verde Rivers, as well as the Central Arizona Project, which transports water from the Colorado River, have enabled the rapid growth of this city during the latter half of the 20th century into a major metropolitan center with diverse tree plantings. United States (2010) census data indicates that the population of Maricopa County increased by $24.2 \%$ since 2000 to more than 3.8 million (U.S. Census 2010).

Many urban forests, especially in arid systems, have been created and managed by humans (Whitney and Adams 1980; Martin 2008). The constructed urban forest in the greater Phoenix area is of necessity, irrigated, and has been characterized as having a lower species richness but a much larger species pool and canopy cover compared to the surrounding Sonoran Desert (Martin et al. 2003; Walker et al. 2009). Because of this, the carbon acquisition potential of local irrigated landscape vegetation has been estimated to be more than eight times greater than that of vegetation in the surrounding Sonoran Desert (Martin and Stabler 2002).

Landscaping, or the practice of creating, installing, and managing outdoor human living environments for the enhancement of everyday quality of human life, is shaped by a complex interaction of socioeconomic values, the needs of society, and technologies, such as irrigation and air conditioning (Motloch
1991). Before 1960 and the advent of the common use of air conditioning, one of the principle ways that trees in Phoenix served the needs of society was to make outdoor living spaces more habitable by ameliorating extremely high summer temperatures through shading and evapotranspirational cooling. To accomplish this, landscape designs were characterized by the presence of fast-growing broadleaf deciduous shade trees, such as mulberry (Morus alba) or Texas umbrella tree (Melia azedarach). Since 1960, the functional role of outdoor landscapes in the Phoenix area has waned as residents generally spend an increasingly greater portion of time inside controlled atmospheric environments. Especially since 1990, landscape function, as a measure of the value of outdoor living space, has been superseded by landscape form driven by increasing public interest in conservation of water resources and native Sonoran Desert flora. Evidence for this change in the role of Phoenix outdoor landscapes may be seen in the widespread planting of desertadapted trees, such as blue palo verde (Parkinsonia florida) and South American mesquite hybrid (Prosopis alba $\mathrm{x}$ Prosopis chilensis). Presently, the role of outdoor amenity landscapes may be to visually enhance the human living experience, while reflecting an attempt to conserve natural resources and offer city-dwellers an opportunity to comfortably experience nature.

Urbanization can cause a dramatic shift in plant diversity and community composition, especially in arid regions. This might be explained by the broad introduction of nursery-cultivated exotic species within an urban area. Urban tree diversity and abundance in Phoenix has been shown to be positively correlated with socioeconomic status (Hope et al. 2003; Martin et al. 2004). Recently, researchers reported that since 1970 the abundance of urban forest cover in Phoenix, as measured by NDVI (normalized difference vegetation index), has increasingly become positively correlated to average income (Jenerette et al. 2011). 
Sustainable urban forests in the southwestern United States should be designed, installed, and managed by people in ways that are able to improve human health, quality of life, and commerce without excessive consumption of natural resources (Martin 2008). A holistic knowledge of the impact of landscape design and management practices on overall urban forest function is essential to ensure urban tree health and longevity. In Phoenix, the authors have noted anecdotally that the intensity of urban tree care practices, such as crown raising and crown thinning, generally appear to be greater at commercial, industrial, and public sites as well as transportation corridors, such as streetscapes and landscaped interstate highways, than at residential sites. These differences in management intensity are probably caused by the greater likelihood that landscape plantings within non-residential landuses are managed more regularly by professional landscape maintenance companies than those within residential areas. In hot desert regions, excessive pruning of landscape trees might predispose some tree taxa to locally common abiotic stressors, such as trunk and crown sunscald injury, which can be linked to biotic stressors, such as wood decay and sooty canker.

Assessments of tree health in urban landscapes are rare (Cumming et al. 2001). Monitoring urban forest health is essential to identifying changes within urban ecosystems as well as providing a foundation for improving resource management practices (McPherson 1993). In this paper, researchers present an overview of two long-term field studies on the health and role of trees in the Phoenix metropolitan area. While the term plant health is abstract and has no universal definition (Doring et al. 2012), the authors evaluated tree health in Phoenix using two commonly accepted indicators: crown condition and the absence of external symptoms and signs of disease causing agents, pests, and abiotic or stress problems (Kolb et al. 1994).

\section{METHODS}

The following is a description of the two long-term field studies that were used to present an overview of the health and mortality of trees in the Phoenix metropolitan region. Both studies are a part of the Central Arizona Long-Term Ecological Research (CAP LTER) project that was initiated in 1998 to study ecosystem dynamics across the Phoenix metropolitan region.

\section{Survey 200}

This extensive survey is an integral part of the CAP LTER monitoring program and consists of 204 sites distributed across the Phoenix metropolitan basin and surrounding Sonoran Desert, encompassing a total area of $6,400 \mathrm{~km}^{2}$. Each site has an area of approximately $900 \mathrm{~m}^{2}$. These 204 sites are arrayed in a dual-density, randomized, tessellation-stratified design (Hope et al. 2003) to enable characterization of landuse patches in terms of key biotic, physical, and chemical variables, and to examine relationships between land-use, general plant diversity, native plant diversity, plant volume, soil nutrient status, and socioeconomic indices along an indirect urban gradient. Between February and April 2010, researchers surveyed all 204 sites for the presence of trees and segregated them taxonomically, using JMP 8.0 (SAS, Cary, North Carolina, U.S.). The study authors defined a tree as being a woody plant having one or more erect perennial stem (trunk) with a cumulative diameter of at least $7.6 \mathrm{~cm}$ at a point $1.37 \mathrm{~m}$ above the ground, a formed crown of foliage, and a mature height of at least $3.0 \mathrm{~m}$. Next, within a subset of sites classified as urban $(\mathrm{N}=104$ of 204), the overall crown condition of trees was visually evaluated and rated as either very good (4), good (3), fair (2), or poor (1) based on a matrix of condition factors used for plant appraisal (CTLA 1992).

\section{3-2007 Non-residential Tree Survey}

Records of tree mortality were made annually (2003-2007) during winter months at 50 irrigated sites with immediate public access (commercial, institutional, or transportation land-uses). The 50 sites were arrayed in a broad northwest to southeast transect gradient across the region. Within this transect gradient, sites were distributed equally using the Burgess Urban Land Use Model of monoconcentric circles, expanding from the urban core to urban fringe into seven previously defined concentric zones (bandwidth of $6.5 \mathrm{~km}$ ) of air temperature and atmospheric $\mathrm{CO}_{2}$ level (Stabler and Martin 2000). Each site averaged $930 \mathrm{~m}^{2}$ in area and contained approximately eight trees, 402 total established trees ( 36 unique taxa) at the 50 sites in 2003 . In this paper, researchers present tree mortality rates from this population of trees over a five-year period. No data were collected on trees planted within sites after the start of the data collection period.

During winter 2006-2007, data about tree crown condition were collected at these 50 sites plus 15 additional nonresidential locations selected from the CAP LTER 200 point survey sites $(\mathrm{N}=707)$. For each tree, the overall condition was evaluated and rated as very good, good, fair, or poor, based on condition factors used for plant appraisal (CTLA 1992). Each tree was assessed for the absence or presence of known biotic concerns (diseases and pests) common to urban tress in Phoenix, including slime flux, ash decline, sooty canker, Verticillium wilt, wood rot, Phymatotrichopsis root rot, fire blight, true mistletoe, aphids, sapsucker bird damage, as well as for abiotic problems (stress and problems with unknown etiology) common in urban trees in Phoenix, including sunscald, pine blight, chlorosis, and leaf margin necrosis (Streets 1969; Olsen 2001; Bricker and Stutz 2004). Physical and mechanical damage to roots, trunks, or branches of each tree was assessed using the protocol of Cummings et al. (2001), and the location, types, and severity of damage was recorded.

For both studies, all sites were classified according to the Maricopa Association of Governments (MAG) landuse classification system. Sites included a variety of desert and residential and non-residential urban land-use types, including industrial, institutional, transportation (streetscapes) and golf courses parks, and urban waterways.

\section{RESULTS}

\section{Survey 200}

Across the whole study area, 165 of the 204 sites were located within the Phoenix metropolitan area. The remaining 39 sites were external to the city within the surrounding Sonoran Desert. Across the whole study area, 641 trees were found distributed across 130 of the 204 sites, with 401 trees occurring at 104 of the 165 sites within the metropolitan area. In Table 1, researchers show the taxonomic distribution of these 401 trees within 
the Phoenix metropolitan area by botanical family. Interestingly, $44.5 \%$ of these 401 trees were of the family Fabaceae. Of the trees in the family Fabaceae, $63.4 \%$ belonged to two desert-adapted genera, Parkinsonia and Prosopis. Table 2 shows the percentage distribution of crown condition ratings for trees at landscaped sites by four dominant urban land classification types. Overall, crown condition was rated very good for $42 \%$ and good for $42 \%$ of the trees with a mean crown condition rating of 3.2. When data were analyzed using MAG land-use classification types for each plot, residential sites had the greatest percentage of tree crowns

Table 1. Numerical distribution of taxonomic families of landscape trees found at sites within the Phoenix metropolitan area during spring 2010. Also shown is the numerical distribution of landscape tree genera within the family Fabaceae within the Phoenix metropolitan area during spring 2010.

\begin{tabular}{|c|c|c|}
\hline Taxonomic family & Count & Proportion \\
\hline Anacardiaceae & 13 & 0.032 \\
\hline Arecaceae & 21 & 0.051 \\
\hline Bignoniaceae & 5 & 0.012 \\
\hline Cupressaceae & 4 & 0.009 \\
\hline Fabaceae & 181 & 0.445 \\
\hline Fagaceae & 7 & 0.017 \\
\hline Juglandaceae & 2 & 0.004 \\
\hline Meliaceae & 5 & 0.012 \\
\hline Moraceae & 19 & 0.046 \\
\hline Myrtaceae & 5 & 0.012 \\
\hline Oleaceae & 27 & 0.066 \\
\hline Pinaceae & 11 & 0.027 \\
\hline Platanaceae & 2 & 0.004 \\
\hline Rosaceae & 8 & 0.019 \\
\hline Rutaceae & 42 & 0.103 \\
\hline Salicaeae & 4 & 0.009 \\
\hline Sterculiaceae & 18 & 0.044 \\
\hline Tamaricaeae & 3 & 0.007 \\
\hline Ulmaceae & 27 & 0.066 \\
\hline Verbenaceae & 2 & 0.004 \\
\hline Total & 406 & 1.00000 \\
\hline Taxonomic genus & Count & Proportion \\
\hline Acacia & 15 & 0.082 \\
\hline Bauhinia & 2 & 0.011 \\
\hline Dalbergia & 9 & 0.049 \\
\hline Ebenopsis & 3 & 0.016 \\
\hline Leucaena & 5 & 0.027 \\
\hline Lysiloma & 12 & 0.066 \\
\hline Mariosousa & 1 & 0.005 \\
\hline Olneya & 7 & 0.038 \\
\hline Parkinsonia & 76 & 0.419 \\
\hline Prosopis & 39 & 0.215 \\
\hline Quercus & 1 & 0.005 \\
\hline Tipuana & 1 & 0.005 \\
\hline Vachellia & 10 & 0.055 \\
\hline Total & 181 & 1.000 \\
\hline
\end{tabular}

Table 2. Percentage distribution of crown condition ratings for trees at landscaped sites by land-use that were part of the 2010 CAP LTER Survey 200 project.

\begin{tabular}{lllll}
\hline Rating & Commercial $^{\mathrm{z}}$ & Institutional & Transport & Residential \\
\hline Very Good & $27 \%$ & $19 \%$ & $26 \%$ & $50 \%$ \\
Good & $50 \%$ & $52 \%$ & $40 \%$ & $42 \%$ \\
Fair & $15 \%$ & $19 \%$ & $27 \%$ & $6 \%$ \\
Poor & $8 \%$ & $10 \%$ & $7 \%$ & $2 \%$ \\
\hline
\end{tabular}

${ }^{\mathrm{z}}$ Survey sites were classified using Maricopa Association of Governments land-use classification types. Survey assessment from February to April 2010; $\mathrm{N}=33,27$, 54 , and 273 for commercial, institutional, transport, and residential, respectively. that were rated in very good condition and the least percentage of tree crowns rated that were rated in either fair or poor condition. About one-half of trees found at commercial and institutional sites had crowns that were rated in good condition. Nearly one-third of the crowns of trees located at institutional sites and along transportation corridors were rated in either fair or poor condition, compared with only $8 \%$ of trees at residential sites.

\section{3-2007 Non-residential Tree Survey}

Over the five-year period, the number of trees at the 50 nonresidential sites in the greater Phoenix area declined from 403 to 335 , suggesting a $4.2 \%$ average annual rate of tree mortality. Table 3 shows the percentage distribution of crown condition ratings and types of problems of trees at the 50 non-residential sites plus the 15 non-residential sites selected from the Survey 200 study (65 total sites) during the winter of 2006-2007. The overall mean crown condition rating of trees sampled at these 65 sites was 2.6 (between fair and good). Although a majority of the tree crowns were rated as very good $(17 \%)$ or good $(44 \%)$, it was found that $15 \%$ of tree crowns were in poor condition. Biotic problems (diseases and pests) were visually detected for $41 \%$ of the trees, whereas abiotic problems were observed for about $23 \%$ of trees. Of the trees with crowns rated in poor condition, $90 \%$ had significant biotic and abiotic problems. Significant canopy dieback occurred in $17 \%$ of the trees and was associated with known disease problems in Fraxinus (ash decline caused by phytoplasmas) and Olea (Verticillium wilt), but was also associated with problems of unknown etiology in Pinus (pine blight) and Rhus trees. Other common disease and pest problems observed included slime flux, sooty canker, wood rot, aphids, and sapsucker bird damage. Sunscald of bark on the bole was the most common abiotic problem. Pruning problems including topping, bark tearing, presence of large stub, and flush cuts were observed for $70 \%$ of the trees. Physical/mechanical injury (greater than $5 \mathrm{~cm}$ in diameter) to roots, the trunk, or main scaffold branches was detected in close to half of the trees (ca. 46\%). Wounding appeared to be mostly associated with damage caused by landscape maintenance equipment, automobile impacts, and vandalism.

The mean crown condition and percentage of occurrence of biotic and abiotic problems of trees in the 11 most common botanical taxa are shown in Table 4. Overall, the crown condition rating of Ulmus trees was highest and Quercus trees were

Table 3. Percentage distribution of crown condition ratings and type of problem, biotic (disease and pest), abiotic, poor pruning, or wounding of landscape trees at 65 non-residential sites in the Phoenix metropolitan area. Non-residential survey assessment was during winter 2006-2007 ( $N=707)$.

\begin{tabular}{ll}
\hline Condition rating & $\%$ of all trees \\
\hline Very Good & $17 \%$ \\
Good & $44 \%$ \\
Fair & $24 \%$ \\
Poor & $15 \%$ \\
\hline Type Problem & $\%$ of all trees \\
\hline Abiotic problems & $23.2 \%$ \\
Biotic problems & $41.0 \%$ \\
Poor pruning & $70.4 \%$ \\
Wounding $>5 \mathrm{~cm}$ & $45.8 \%$ \\
diameter &
\end{tabular}


Table 4. Mean crown condition rating and associated biotic and abiotic problems for 11 common landscape tree genera assessed at 65 non-residential landscaped sites in the Phoenix metropolitan area. Non-residential survey assessment was during winter 2006-2007 ( $N=707$ ).

\begin{tabular}{|c|c|c|c|c|c|c|}
\hline Genera taxa & $\mathrm{N}$ & Crown rating & Biotic & Primary problem & Abiotic & Primary problem \\
\hline$\overline{\text { Acacia }}$ & 64 & $3.03^{z}$ & $38 \%$ & Slime flux & $3 \%$ & \\
\hline Brachychiton & 53 & 2.42 & $49 \%$ & Sooty canker & $49 \%$ & Sunscald \\
\hline Eucalyptus & 40 & 2.35 & $35 \%$ & Slime flux & $25 \%$ & Iron chlorosis \\
\hline Olea & 60 & 2.35 & $30 \%$ & Verticillium wilt & $40 \%$ & Sunscald \\
\hline Parkinsonia & 63 & 2.79 & $44 \%$ & Slime flux & $5 \%$ & \\
\hline Pinus & 73 & 2.49 & $34 \%$ & Bird damage & $53 \%$ & Pine blight \\
\hline Prosopis & 73 & 3.04 & $67 \%$ & Slime flux & $0 \%$ & \\
\hline Rhus & 49 & 2.39 & $18 \%$ & Wood rot & $29 \%$ & Dieback \\
\hline Ulmus & 56 & 3.35 & $25 \%$ & Sooty canker & $2 \%$ & \\
\hline
\end{tabular}

${ }^{\mathrm{z}}$ Crown rating: 1 = Poor; 2 = Fair; 3 = Good; and 4 = Very Good.

lowest. Some biotic and abiotic problems were associated with certain genera. For example, slime flux was detected in Acacia Parkinsonia, and Prosopis trees. Sooty canker was most commonly observed in Brachychiton and Ulmus trees. Aphids were only detected on Quercus and Fraxinus trees. Wood-pecking bird damage and pine blight were primary problems observed on Pinus trees. Sunscald injury of trunk and branch tissues was most commonly detected on Brachychiton, Olea, and Quercus trees.

\section{DISCUSSION}

Although crown condition was rated as very good or good for the majority of trees at both residential and non-residential sites, researchers found that residential trees in Phoenix had generally fewer visual health issues than trees in non-residential settings. Urban forests are a complex and diverse mixture of trees of many taxa and age classes. In these studies, researchers were able to differentiate grouping of trees by species composition, but not by age class. As a result, authors were not able to assign age class as an independent variable to determine if differences in canopy condition were related to tree age differences within each urban land-use type. The authors recognize the potential limitations of these health data due to differential mortality and dieback of older trees. In addition, the above- and belowground environmental conditions within which urban trees grow can range from excellent to being severely constricted by the built environment, and it is possible that environmental constrictions in Phoenix to tree productivity are more severe at non-residential sites. Despite these limitations, the study authors believe that valuable insights were gained regarding overall trends of tree health related to broad measures of urban classification, such as urban land-use from the citywide survey data presented in this paper.

When tree visual health was scrutinized in greater detail, a diverse set of abiotic and biotic stressors were detected at nonresidential sites. Half of the trees had major physical wounds present on their trunks, main scaffold branches, or roots, whereas $70 \%$ had pruning problems. While researchers could not determine with certainty if pruning problems were caused by the removal of dead branches on older or diseased trees or associated with the training of the crown architectures of young trees, researchers suspect that most pruning problems are associated with intensive crown management of young trees. The majority of development (by land area) in the Phoenix metropolitan area has occurred within that last 50 years, with a significant portion of that during the last 20 years (Larson et.al. 2005). Therefore, it is reasonable to surmise that pruning strategies for trees planted in landscaped areas of this large portion of the city are focused on live crown management and not the removal of dead branches associated mature trees with significant crown dieback.

Biotic problems were detected in just over $40 \%$ of the trees at non-residential sites and biotic problems were detected in most trees with poor crown condition ratings. These biotic problems were often species-specific and included diseases of common landscape trees in the Phoenix area, including ash decline in Fraxinus and Verticillium wilt in Olea, both of which can cause significant canopy dieback. Other biotic problems were specific abiotic conditions, including slime flux in desert-adapted Parkinsonia and Prosopis, which was associated with pruning wounds, and sooty canker in Brachychiton trees, which was associated with sunscald. It was found that the mortality rate for the trees that were monitored at non-residential sites for the five years averaged about $4.2 \%$ per annum. This mortality rate is similar to that previously reported by Nowak et al. (2004) for Baltimore, Maryland, U.S.

In cities across the United States, a tree planting campaign is one strategy used to increase urban forest cover density and diversity and to mitigate atmospheric pollution, urban heating, and improve urban ecosystem function (Stone and Rodgers 2001; Kalnay and Cai 2003; Jenerette et al. 2007). For example, Phoenix's tree and shade master plan provides a framework to achieve an average $25 \%$ tree canopy coverage by 2030 (City of Phoenix Tree and Shade Master Plan). In Phoenix, the combination of heightened public awareness about landscape water conservation and advocacy of the use of low-water-use trees has resulted in the increased planting of trees in the family Fabaceae and in particular desert-native trees, such as those in the genera Parkinsonia and Prosopis, during the last 20 years.

Desert-adapted and desert-native trees, such as Parkinsonia and Prosopis, usually have broadly spreading, complex crown structures that sometimes extend fully to the ground as a normal morphological adaptation to an arid climate. In Phoenix, these trees are often planted into non-residential sites, such as parking medians and transportation corridors, with severe above- and belowground spatial limitations due to the density of the built environment and/or because local ordinances stipulate that scaffold branches must originate from trunks no lower than a height of $3.6 \mathrm{~m}$. Management strategies for trees in these difficult sites include extensive removal of live stems and branches through pruning practices, such as crown raising, thinning, and crown reduction. The authors 
suggest that these practices may be one explanation for the high percentage of pruning problems that were observed on trees, especially those at non-residential sites. Moreover, these management practices might also be one cause of the many abiotic problems, such as sunscald of trunk phellem, or the biotic problems, such as sooty canker and slime flux, both of which were commonly observed in this study.

\section{CONCLUSION}

Based on the studies presented in this paper, researchers conclude that although crown condition was relatively good for the majority of trees assessed in the Phoenix metropolitan area, a diverse set of biotic and abiotic conditions associated with intensive crown management has had an apparent negative impact on tree health. It is within this context that the authors propose that arborists and landscape managers in desert cities such as Phoenix implement practices to improve urban forest sustainability, such as 1) selecting trees with mature crown projections and rooting volumes that are compatible with above- and belowground site restrictions; 2) emphasize the training of young trees to develop sitecompatible crown structures, rather than use corrective pruning of mature trees; and 3) utilize water-conserving irrigation technologies to optimize rates of irrigation water delivery to tree evapotranspirational demand, so as to not overly stimulate tree productivity, particularly of low-water-use or desert trees.

Acknowledgments. This material is based upon work supported by the National Science Foundation under grant no. DEB-0423704: CAP2 (2004-2010), Central Arizona-Phoenix Long-Term Ecological Research (CAP LTER).

\section{LITERATURE CITED}

Bricker, J.S., and J.C. Stutz. 2004. Phytoplasmas associated with ash decline. Journal of Arboriculture 30:193-199.

CAP LTER (Central Arizona Long-Term Ecological Research). Accessed 07/26/2012. <http://caplter.asu.edu>

City of Phoenix Tree and Shade Master Plan. Accessed 04/03/2012. <http://phoenix.gov/webcms/groups/internet/@inter/@dept/@parks/ documents/web_content/071957.pdf>

CTLA (Council of Tree and Landscape Appraisers). 1992. Guide for Plant Appraisal, 8th Edition. International Society of Arboriculture, Champaign, Illinois, U.S. 103 pp.

Cumming, A.B., M.F. Galvin, R.J. Rabaglia, J.R. Cumming, and D.B. Twardus. 2001. Forest health monitoring protocol applied to roadside trees in Maryland. Journal of Arboriculture 27:126-138.

Doring, T.F., M. Pautasso, M.R. Finchkh, and M.S. Wolfe. 2012. Concepts of plant health: Reviewing and challenging the foundations of plant protection. Plant Pathology 61:1-15.

Hope, D., C. Gries, W. Zhu, W.F. Fagan, C.L. Redman, N.B. Grimm, A.L. Nelson, C.A. Martin, and A. Kinzig. 2003. Socio-economics drive urban plant diversity. Proceedings of the National Academy of Sciences 100(15):8788-8792.

Jenerette, G.D., S.L. Harlan, A. Brazel, N. Jones, L. Larsen, and W.L. Stefanov. 2007. Regional relationships between surface temperature, vegetation, and human settlement in a rapidly urbanizing ecosystem. Landscape Ecology 22:353-365.

Jenerette, G.D., S.L. Harlan, W. Stefanov, and C.A. Martin. 2011. Ecosystem services and urban heat riskscape moderation: Water, green spaces, and social inequality in Phoenix, USA. Ecological Applications 21(7):2637-2651.

Kalnay, E., and M. Cai. 2003. Impact of urbanization and land use change on climate. Nature 423:528-531.

Kolb, T.E., M.R. Wagner, and W.W. Covington. 1994. Concepts of forest health: Utilitarian and ecosystems perspectives. Journal of Forestry 92:10-15. 99

Larson, E.K., N.B. Grimm, P. Gober, and C.L. Redman. 2005. The paradoxical ecology and management of water in the Phoenix, USA metropolitan area. Journal of Ecohydrology \& Hydrobiology 5:287-29.

MAG (Maricopa Association of Governments). Accessed 12/01/2011. $<$ www.azmag.gov>

Martin C.A., and L.B. Stabler. 2002. Plant gas exchange and water status in urban desert landscapes. Journal of Arid Environments 51:235-254.

Martin, C.A. 2008. Landscape sustainability in a Sonoran Desert city. Cities and the Environment 1(2) Article 5:1-16.

Martin, C.A., K.A. Peterson, L.B. Stabler. 2003. Residential landscaping in Phoenix, Arizona: Practices, preferences and covenants codes and restrictions (CC\&Rs). Journal of Arboriculture 29:9-17.

Martin, C.A., P.S. Warren, and A.P. Kinzig. 2004. Neighborhood socioeconomic status is a useful predictor of perennial landscape vegetation in residential neighborhoods and embedded small parks of Phoenix, Arizona. Landscape and Urban Planning 69:355-368.

McPherson, E.G. 1993 Monitoring urban forest health. Environmental Monitoring and Assessment 26:165-174.

Motloch, J.L. 1991. Introduction to Landscape Design. Van Nostrand Reinhold, New York. 307 pp.

Nowak, D.J., M. Kuroda, and D.E. Crane. 2004. Tree mortality rates and tree population projections in Baltimore, Maryland, USA. Urban Forestry \& Urban Greening 2:139-147.

Olsen, M. 2001. Diseases of Urban Plants in Arizona. University of Arizona Extension Publication AZ1124.

Redman, C. 1999. Human Impact on Ancient Environments. University of Arizona Press, Tucson, Arizona, U.Z. 288 pp.

Stabler L.B., and C.A. Martin. 2000. Temporal and spatial patterns of air temperature and $\mathrm{CO}$ concentration in metropolitan Phoenix. Third Symposium on the Urban Environment 3:201-202.

Stone, B., and M.O. Rodgers. 2001. Urban form and thermal efficiency: How the design of cities influences the urban heat island effect. Journal of the American Planning Association 67:186-198.

Streets, R.B. 1969. Diseases of Cultivated Plants of the Southwest. University of Arizona Press, Tucson, Arizona, U.S.

United States Census. 2010. Accessed 12/01/2011. <http://census. gov/2010census>

Walker, J.S., N.B. Grimm, J.M. Briggs, C. Gries, and L. Dugan. 2009. Effects of urbanization on plant species diversity in central Arizona. Frontiers in Ecology and the Environment 7(9):465-470.

Whitney, G.G., and S.D. Adams. 1980. Man as a maker of new plant communities. Journal of Applied Ecology 17:431-448.

Chris A. Martin, Ph.D. (corresponding author)

Professor

School of Letters and Sciences

Arizona State University

6073 South Backus Mall

Mesa, Arizona 85212, U.S.

chris.martin@asu.edu 
Jean C. Stutz, Ph.D.

Professor

School of Letters and Sciences

Arizona State University

6073 South Backus Mall

Mesa, Arizona 85212, U.S.

Zusammenfassung. In dem metropolischen Becken von Phoenix, Arizona, USA, wurden zwei Studien zur Diversität von Bäumen, sichtbarer Gesundheit und Sterberate als Teil eines lang angelegten Ökologischen Forschungsprojektes in Zentral-Arizona durchgeführt. Für die eine Studie wurden in 2010 Baumvielfalt, Sterberate und sichtbare Gesundheit an 204 Standorten bestimmt, die sowohl aus dem metropolischen Becken von Phoenix als auch der umgebenden Wüste von Sonora ausgewählt wurden. In einer anderen Studie wurden Aufzeichnungen zur sichtbaren Baumgesundheit und Sterberate während der Wintermonate (2003-2007) an 65 Standorten um einen urbanen bis ruralen Gradienten gemacht. Die durchschnittliche Baumsterberate lag bei $4.2 \%$ pro Jahr. Der Zustand der Baumkronen wurde für die Mehrzahl der Bäume als sehr gut oder gut bewertet. Schlechte Schnittmaßnahmen und abiotische Verletzungen, so wie Sonnenbrand am Stamm, wurden bei $70 \%$ in besiedelten und 23\% in unbesiedelten Regionen beobachtet. Krankheiten und Probleme durch Insekten wurden bei $41 \%$ der urbanen Bäume entdeckt, einschließlich Verticillium-Welke, Rindenkrebs und Eschensterben. Basierend auf diesen Daten kamen die Forscher zu dem Ergebnis, dass die Gesundheit urbaner Wälder in Phoenix negativ beeinflusst wird durch extreme Verletzungen der Bäume, besonders in unbesiedelten Gegenden, wahrscheinlich verursacht durch exzessive Kronenmanipulation, sprich Schnittmassnahmen.

Resumen. Se llevaron a cabo dos estudios sobre la diversidad de árboles, salud visual y mortalidad en la cuenca metropolitana de Phoenix, Arizona, EE.UU. como parte del proyecto a largo plazo de investigación ecológica de Arizona central. En un estudio, la diversidad de árboles, mortalidad y salud visual se determinaron en 2010 a 204 sitios, que abarca tanto la cuenca metropolitana de Phoenix como los alrededores del Desierto de Sonora. En otro estudio, se tomaron registros de la salud visual del árbol y la mortalidad durante los meses de invierno (20032007) en 65 sitios no residenciales a través de una zona urbana con el gradiente rural. Las tasas promedio de mortalidad de árboles fueron del $4,2 \%$ anual. El estado de las copas fue calificado como muy bueno o bueno para la mayoría de los árboles. Se observaron pobres prácticas de poda y daños abióticos tales como quemaduras del tronco en $70 \%$ y $23 \%$, respectivamente, en zonas no residenciales. Se detectaron problemas de enfermedades y plagas en el $41 \%$ de los árboles urbanos, incluyendo deterioro de la madera, marchitez por Verticillium, hollín de cancro y declinación. Con base en estos datos, los investigadores sugieren que la salud del bosque urbano de Phoenix está siendo afectada negativamente por una extensiva afectación a los árboles, sobre todo en entornos no residenciales, posiblemente causada por la manipulación excesiva de la copa a través de la poda. 